\title{
TWO NEW SPECIES OF THE GENUS CANDIDA FROM WILD GRAPES
}

\author{
SHOJI GOTO AND HIROYUKI OGURI \\ The Institute of Enology and Viticulture, Yamanashi \\ University, Kofu 400, Japan
}

(Received December 28, 1982)

Two new species of the genus Candida from wild grapes (Vitis coignetiae) in central Japan are described. The new taxa are named Candida agrestis and Candida montana.

In a study of the yeast flora of wild grapes (Vitis coignetiae) in central Japan, two yeasts were found to be previously undescribed representatives of the genus Candida.

\section{MATERIALS AND METHODS}

Yeast cultures. Five yeast strains, No. 611, No. 616, No. 624, No. 865, and No. 868 taken from wild grapes in the Hirose region of Yamanashi Prefecture were examined.

Identification. The descriptions of the species are based on the standard methods adopted for yeast taxonomy (1). YM broth (5 g peptone, $3 \mathrm{~g}$ malt extract, $3 \mathrm{~g}$ yeast extract, and $10 \mathrm{~g}$ glucose in $1,000 \mathrm{ml}$ distilled water) was used for liquid cultures. Fifteen grams of agar was added to YM broth in solid medium.

Biochemical characters. The colour reaction with Diazonium Blue B reagent was tested on 3-week-old cultures on YM agar as described by VAN DER WALT and Hopsu-Havu (2). Vitamin requirements were determined by the method of GoTo (3). Urease activity was determined according to the method of SEELIGER (4). The DNA base composition (GC content) was determined according to the procedure of NAKASE and KOMAGATA (5). The ubiquinone system was determined by the method of YAMADA and Kondo (5). Extracellular DNase was measured by the modified procedure of Sen and Komagata (7) of CAZIN et al. (8).

\section{RESULTS AND DISCUSSION}

Description of Candida agrestis Goto et Oguri sp. nov.

Cultura in YM (peptonum-extractum malto-extractum faecis jus): Post 3 dies 


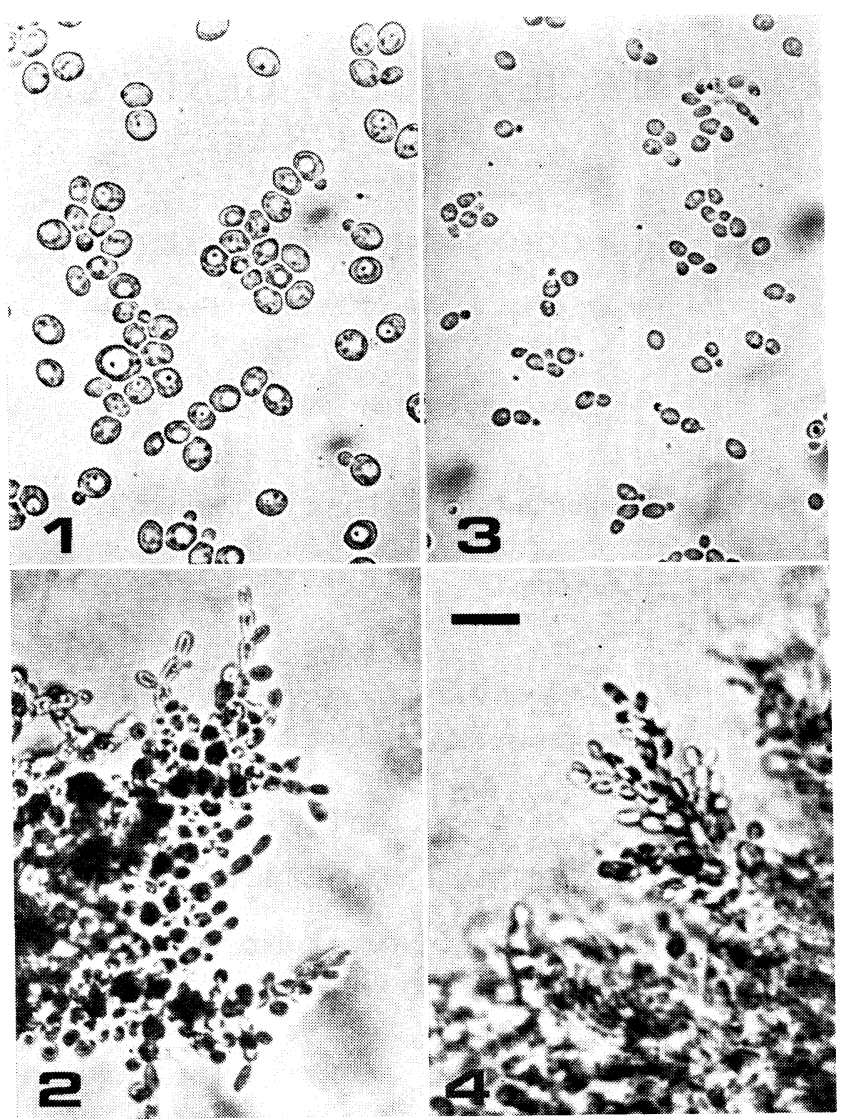

Fig. 1. Vegetative cells of Candida agrestis No. 611 in YM medium after 3 days at $25^{\circ}$.

Fig. 2. Primitive pseudomycelium of Candida agrestis No. 611. Slide culture on potato glucose agar for 7 days at $25^{\circ}$.

Fig. 3. Vegetative cells of Candida montana No. 865 in YM medium after 3 days at $25^{\circ}$.

Fig. 4. Primitive pseudomycelium of Candida montana No. 865. Slide culture on potato glucose agar for 7 days at $25^{\circ}$.

$\operatorname{Bar}=10 \mu \mathrm{m}$.

ad $25^{\circ}$ cellulae ovoideae aut globosae, $3-5 \times 4-6.5 \mu \mathrm{m}$, singulae aut catenatae breves; sedimentum tenuis formantur. Cultura in striis agaro YM; Post unum mensem ad $20^{\circ}$ color cremeus, pagina nitrida et laevis, margo integer. Pseudomycelium primitivum formantur.

Ascosporae, ballistosporae et teliosporae nullae.

Fermentat glucosum. Assimilat glucosum, sucrosum, cellobiosum, trehalosum, raffinosum, melezitosum (exigue), ethanolum, ribitolum (exigue), D-mannitolum, D-glucitolum, alpha-methyl-D-glucosidum (valde exigue), acidum lacti- 
cum (exigue) et acidum succinicum (exigue).

Kalium nitricum non assimilatur, amylum non formatur, ureum non finditur. As crescentiam vitaminae necessariae sunt. In $37^{\circ}$ non crescit. Proportio molaris guanini-cytosini in acido deoxyribonucleico $37.8 \mathrm{~mol} \%$.

Habitat in baccis Vitis coignetiarum.

Holotypus: Stirps 611 ex baccis Vitis coignetiarum, Hirose, Prov. Yamanashi, Japonia, leg. S. Goto, 3. X. 1979 isolata est In collectione culturarum, "The Institute of Enology and Viticulture, Yamanashi University, Kofu", sub RIFY 4611 deposita est.

Growth in YM broth: After 3 days at $25^{\circ}$, cells are oval to globose, $3-5 \times$ 4-6.5 $\mu \mathrm{m}$, single, in pairs and in short chains (Fig. 1). A thin pellicle is formed.

Growth on YM agar: After one month at $20^{\circ}$, the streak culture is creamcolored, glistening, smooth, entire at the margin.

Slide culture on potato-glucose agar: Primitive pseudomycelium is formed (Fig. 2).

Sporulation: No ascospores, ballistospores and teliospores are formed.

Fermentation: Only glucose is fermentation; no other sugars are fermented.

Assimilation of carbon sources:

$\begin{array}{llll}\text { Glucose } & + & \text { D-Ribose } & - \\ \text { Galactose } & - & \text { L-Rhamnose } & - \\ \text { L-Sorbose } & - & \text { Ethanol } & + \\ \text { Sucrose } & + & \text { Glycerol } & - \\ \text { Maltose } & - & \text { Erythritol } & - \\ \text { Cellobiose } & + & \text { Ribitol } & + \text { weak } \\ \text { Trehalose } & + & \text { Galactitol } & - \\ \text { Lactose } & - & \text { D-Mannitol } & + \\ \text { Melibiose } & - & \text { D-Glucitol } & + \\ \text { Raffinose } & + & \alpha \text {-Methyl-D- } & \\ \text { Melezitose } & + \text { weak } & \text { glucoside } & + \text { very weak } \\ \text { Inulin } & - & \text { Salicin } & - \\ \text { Starch } & - & \text { DL-Lactic acid } & + \text { weak } \\ \text { D-Xylose } & - & \text { Succinic acid } & + \text { weak } \\ \text { L-Arabinose } & - & \text { Citric acid } & - \\ \text { D-Arahinose } & - & \text { Inositol } & -\end{array}$

Assimilation of potassium nitrate: Negative.

Growth in vitamin-free medium: Negative. Thiamine and pyridoxine are required for growth.

Sodium chloride tolerance: $3 \%(\mathrm{w} / \mathrm{v})$.

Growth temperature: Positive at $34^{\circ}$, negative at $37^{\circ}$.

Production of starch-like compounds: Negative.

Activities of urease and extracellular DNase: Negative. 
GC content of DNA: $37.8 \mathrm{~mol} \%$.

Coenzyme Q system: Q 7 .

Diazonium Blue B reaction: Negative.

Strains examined: Three strains, No. 611 (holotype), No. 616 and No. 624, were obtained from the berries of Vitis coignetixe, collected at Hirose, Yamanashi Prefecture, October 13, 1979, by S. Goto. The strains 611, 616 and 624 have been deposited in the culture collection of the Institute of Enology and Viticulture, Yamanashi University, Kofu, as RIFY 4611 (No. 611), 4616 (No. 616) and 4624 (No. 624), and in the Centraalbureau voor Schimmelcultures, Delft, as CBS 8055 (RIFY 4611).

Description of Candida montana Goto et Oguri sp. nov.

Cultura in YM (peptonum-extractum malto-extractum faecis jus): Post 3 dies ad $25^{\circ}$ cellulae globosae aut ovoideae, $2-3 \times 2-4.5 \mu \mathrm{m}$, singulae, binae vel catenatae breves; mitivum. Sedimentum formatur. Cultura in striis agaro YM: ad $20^{\circ}$, post unum mensem ad $20^{\circ}$ color cremeus, pagina laevis, margo integer. Pseudomycelium primitivum formatur.

Ascosporae, ballistosporae et teliosporae nullae.

Fermentat glucosum (valde exigue). Assimilat glucosum, sucrosum, cellobiosum, raffinosum (valde exigue), melezitosum (valde exigue), L-rhamnosum, ethanolum, glycerolum, D-mannitolum, D-glucitolum, alpha-methyl-D-glucosidum (valde exigue), salicinum, acidum lacticum, acidum succinicum et acidum citricum.

Kalium nitricum non assimilatur, amylum non formatur, ureum non finditur. Ad crescentiam vitaminae externae non necessariae sunt. In $41^{\circ}$ non crescit. Proportio molaris guanini-cytosini in acido deoxyribonucleico $35.6 \mathrm{~mol} \%$.

Habitat in baccis Vitis coignetiarum.

Holotypus: Stirps 865 ex baccis Vitis coignetiarum, Hirose, Prov. Yamanashi, Japonia, leg. S. Goto, 27. IX. 1978 isolata est. In collectione culturarum, "The Institute of Enology and Viticulture, Yamanashi University, Kofu", sub RIFY deposita est.

Growth in YM: After 3 days at $25^{\circ}$, cells are globose to oval, $2-3 \times 2$ $4.5 \mu \mathrm{m}$, single, in pairs or in short chains (Fig. 3). A sediment is formed.

Growth on YM agar: After one month at $20^{\circ}$, the streak culture is creamcolored, smooth, entire at the margin.

Slide culture on potato-glucose agar: Primitive pseudomycelium is formed (Fig. 4).

Sporulation: No ascospores, ballistospores, and teliospores are formed.

Fermentation: Very weak positive, glucose only, no other sugars are fermented.

Assimilation of carbon sources:

$\begin{array}{ll}\text { Glucose } & + \\ \text { Galactose } & -\end{array}$
D-Ribose

L-Rhamnose 


$\begin{array}{llll}\text { L-Sorbose } & - & \text { Ethanol } & + \\ \text { Sucrose } & + & \text { Glycerol } & + \\ \text { Maltose } & - & \text { Erythritol } & - \\ \text { Cellobiose } & + & \text { Ribitol } & - \\ \text { Trehalose } & - & \text { Galactitol } & - \\ \text { Lactose } & - & \text { D-Mannitol } & + \\ \text { Melibiose } & - & \text { D-Glucitol } & + \\ \text { Raffinose } & + \text { very weak } & \alpha \text {-Methyl-D- } & \\ \text { Melezitose } & + \text { very weak } & \text { glucoside } & + \text { very weak } \\ \text { Inulin } & - & \text { Salicin } & + \\ \text { Starch } & - & \text { DL-Lactic acid } & + \\ \text { D-Xylose } & - & \text { Succinic acid } & + \\ \text { L-Arabinose } & - & \text { Citric acid } & + \\ \text { D-Arabinose } & - & \text { Inositol } & -\end{array}$

Assimilation of potassium nitrate: Negative.

Growth in vitamin-free medium: Very weak growth.

Vitamin stimulating growth: Biotin, thiamine, and pyridoxine.

Sodium chloride tolerance: $6 \%(\mathrm{w} / \mathrm{v})$.

Growth at $37^{\circ}$ : Positive; at $41^{\circ}$ : Negative.

Production of starch-like compounds: Negative.

Activities of urease and extracellular DNase: Negative.

GC content of DNA: $35.6 \mathrm{~mol} \%$.

Coenzyme Q system: Q 7 .

Diazonium Blue B reaction: Negative.

Strains examined: Two strains, No. 865 (holotype) and No. 868, were isolated from Vitis coignetiae at Hirose, Yamanashi Prefecture, September 27, 1978 by S. Goto. The strains 865 and 868 have been deposited in the Culture Collection of the Institute of Enology and Viticulture, Yamanashi University, Kofu, as RIFY 4865 (No. 865) and 4968 (No. 868), and in the Centraalbureau voor Schimmelcultures, Delft, as CBS 8057 (RIFY 4865).

The two yeasts $C$. agrestis and $C$. montana from wild grapes (Vitis coignetiae) were classified in the genus Candida because they do not form ascospores, ballistospores, and teliospores and do not produce carotenoid pigments.

C. agrestis and C. montana ferment only glucose. The assimilation patterns of the carbon compounds of the two yeasts are unlike those of any of the known nitrate-negative, the low GC content (below $40 \mathrm{~mol} \%$ ), and urease- and DNasenegative Candida species. The two species are in the delimitation of the genus Torulopsis Berless. Yarrow and MeYer (9) proposed an amendment of the diagnosis of the genus Candida Berkhout to include non-hyphal species. In accordance with the amended description, these yeasts are classified in the genus Candida. 
Distribution of the yeasts on wild grapes will be reported in a separate paper (10).

The authors are grateful to Assoc. Prof. Dr. J. Sugiyama of the University of Tokyo, for his correction of the Latin description. The authors thank Prof. Dr. K. Komagata and Dr. J. Lee of the University of Tokyo and Assoc. Prof. Dr. R. Aono of Yamanashi University, for the determination of the GC content. The authors wish to thank Dr. D. Yarrow of Centraalbureau voor Schimmelcultures, Yeast Division, the Netherlands, for his comments and for reading the manuscript.

\section{REFERENCES}

1) J. P. Van Der Walt, In The Yeasts, ed. by J. Lodder, North Holland Publ. Co., Amsterdam (1970), p. 34.

2) J. P. Van Der Walt and V. K. Houps-Havu, Antonie van Leeuwenhoek J. Microbiol. Serol., 42, 157 (1976).

3) S. Goто, J. Ferment. Technol., 39, 705 (1961).

4) H. P. R. Seeliger, J. Bacteriol., 72, 127 (1956).

5) T. Nakase and K. Komagata, J. Gen. Appl. Microbiol., 14, 345 (1968).

6) Y. Yamada and K. Kondo, J. Gen. Appl. Microbiol., 19, 59 (1973).

7) K. Sen and K. Komagata, J. Gen. Appl. Microbiol., 25, 127 (1979).

8) J. Cazin, T. R. Kozel, D. M. Lupan, and W. R. Burt, J. Bacteriol., 100, 760 (1969).

9) D. YARrow and S. A. MeYer, Int. J. Syst. Bacteriol., 28, 611 (1978).

10) S. Goto and H. OGuRI, Trans. Mycol. Soc. Japan, in press. 